Rafą MichaŁowski ${ }^{1}$

\title{
Sytuacja prawna dzierżawcy w obrębie regulacji dotyczącej nabycia nieruchomości z Zasobu Własności Rolnej Skarbu Państwa w razie wyłączenia $30 \%$ użytków rolnych z umowy dzierżawy
}

Regulacja prawna nabycia nieruchomości rolnej przez dzierżawcę w razie wyłączenia części użytków rolnych z umowy dzierżawy na podstawie art. 4 ustawy z dnia 16 września 2011 r. o zmianie ustawy o gospodarowaniu nieruchomościami rolnymi Skarbu Państwa oraz o zmianie niektórych innych ustaw ${ }^{2}$ przysparza wiele problemów interpretacyjnych. Ich źródłem jest przede wszystkim daleka od jakichkolwiek kanonów poprawnej legislacji treść art. 4 ustawy zmieniającej. Powyższa regulacja doczekała się wypowiedzi w literaturze, gdzie analizowano sytuację prawną dzierżawcy w jej kontekście ${ }^{3}$. Wywołuje ona również duże wątpliwości w orzecznictwie. Skupiają się one wokół zagadnienia, czy dzierżawcy przysługuje roszczenie o zawarcie umowy sprzedaży nieruchomości czy też jego sytuacja prawna charakteryzowana być powinna w ramach konstrukcji pierwszeństwa w nabyciu nieruchomości.

Zgodnie z treścią art. 4 ust. 7 ustawy zmieniającej, w przypadku dokonania zmiany umowy dzierżawy, o której mowa w ust. 5, dzierżawcy przysługuje uprawnienie do zakupu całości albo za zgodą Agencji Nieruchomości Rolnych ${ }^{4}$ części nieruchomości, która pozostała przedmiotem dzierżawy, na zasadach określonych w ustawie z dnia 19 października 1991 r. o gospodarowaniu nieruchomościami

$1 \quad$ Uniwersytet w Białymstoku. Publikacja dofinansowana przez Wydział Prawa Uniwersytetu w Białymstoku.

$2 \quad$ Dz.U. nr 233 poz., 1382, zwana dalej ustawą zmieniającą.

3 A. Suchoń, Z prawnej problematyki gospodarowania na dzierżawionych gruntach rolnych, „Studia luridica Agraria" 2011, t. IX; M. Lemkowski, Uprawnienie dzierżawcy do zakupu nieruchomości rolnej w następstwie częściowego rozwiązania umowy dzierżawy, „Przegląd Prawa Rolnego” 2016, nr 1; Z. Truszkiewicz, Glosa do uchwały Sądu Najwyższego z dnia 15 października 2017 r., III CZP 45/17, „Krakowski Przegląd Notarialny” 2018, nr 3.

$4 \quad$ Zob. art. 45 ust. 1 ustawy z dnia 10 lutego 2017 r. - Przepisy wprowadzające ustawę o Krajowym Ośrodku Wsparcia Rolnictwa (Dz.U. poz. 624), zgodnie z którym zostaje zniesiona Agencja Nieruchomości Rolnych z dniem 31 sierpnia 2017 r., a nowo tworzony, na mocy postanowień ustawy z dnia 10 lutego 2017 r. o Krajowym Ośrodku Wsparcia Rolnictwa (Dz.U. poz. 623), podmiot o tej nazwie z dniem 1 września 2017 r. wstępuje w ogół praw i obowiązków znoszonej Agencji Nieruchomości Rolnych. 
rolnymi Skarbu Państwa ${ }^{5}$ z zastosowaniem prawa pierwszeństwa, o którym mowa w art. 29 u.g.n.r., niezależnie od faktycznego czasu trwania umowy dzierżawy.

Oświadczenie o skorzystaniu z uprawnienia do zakupu, o którym mowa powyżej, dzierżawca składa Agencji Nieruchomości Rolnych w formie pisemnej wraz z oświadczeniem o przyjęciu zaproponowanych przez Agencję Nieruchomości Rolnych zmian umowy dzierżawy, podając termin, w którym dokona tego zakupu. Termin ten nie może być krótszy niż 3 miesiące od dnia dokonania zmiany umowy dzierżawy, o której mowa w ust. 5, i dłuższy niż:

1) 2 lata, jeżeli okres, na jaki została zawarta umowa dzierżawy, upływa nie później niż po 5 latach od dnia dokonania zmiany umowy dzierżawy;

2) 4 lata, jeżeli okres, na jaki została zawarta umowa dzierżawy, upływa po 5 latach od dnia dokonania zmiany umowy dzierżawy i nie później niż po 10 latach od dnia dokonania zmiany umowy dzierżawy;

3) 6 lat, jeżeli okres, na jaki została zawarta umowa dzierżawy, upływa później niż po 10 latach od dnia dokonania zmiany umowy dzierżawy.

W przypadku zaś przeznaczenia nieruchomości lub jej części na cele nierolnicze w miejscowym planie zagospodarowania przestrzennego, studium uwarunkowań i kierunków zagospodarowania przestrzennego gminy lub decyzji o warunkach zabudowy i zagospodarowania terenu, zgodnie z postanowieniem art. 4 ust. 9 ustawy zmieniającej uprawnienie do zakupu, o którym mowa w ust. 7, przysługuje po uzyskaniu zgody Agencji Nieruchomości Rolnych.

Kwestia ta od początku budziła rozbieżności w orzecznictwie sądowym ${ }^{6}$. Szczególną wagę przypisać należy tu uchwale Sądu Najwyższego z dnia 19 października 2017 r. ${ }^{7}$ Sąd Najwyższy rozstrzygnął, że dzierżawcy, który na podstawie art. 4 ust. 7 ustawy zmieniającej złożył ANR (KOWR) oświadczenie o skorzystaniu z uprawnienia do zakupu dzierżawionej nieruchomości rolnej Skarbu Państwa z zastosowaniem prawa pierwszeństwa przewidzianego $\mathrm{w}$ art. 29 u.g.n.r., nie przysługuje roszczenie o zawarcie umowy sprzedaży.

Sąd Najwyższy wskazał, że treść art. 4 ust. 7 ustawy zmieniającej jest źródłem zasadniczych wątpliwości interpretacyjnych w związku z występowaniem w nim równolegle określeń „,uprawnienie do zakupu” oraz „,na zasadach i z zastosowaniem prawa pierwszeństwa". Stojąc na stanowisku, że dzierżawcy na gruncie tej regulacji przysługuje pierwszeństwo w nabyciu nieruchomości a nie roszczenie o zawarcie umowy sprzedaży, na jego poparcie przedstawił szereg argumentów.

Dz.U. z 2018 r., poz. 91 ze zm., określana dalej jako „u.g.n.r.”

Zob. orzeczenia przywołane przez M. Lemkowskiego, zob. tegoż, Uprawnienie dzierżawcy..., op. cit., s. 146.

Sygn. akt III CZP 45/17, „Orzecznictwo Sądu Najwyższego Izba Cywilna” 2018 nr 5, poz. 48, jakkolwiek trzeba zauważyć, że poglądy Sądu Najwyższego w niej wyrażone nie znajdują jednolicie uznania w judykaturze; zob. wyrok Sądu Okręgowego w Szczecinie z dnia 12 marca 2018 r., VIII GC 42/16. 
Sytuacja prawna dzierżawcy w obrębie regulacji dotyczącej nabycia nieruchomości...

Sąd Najwyższy stwierdził, że analizowana regulacja ma charakter epizodyczny. Ponadto brak jest w treści art. 4 ust. 7 zwrotów wprost wskazujących, abyśmy mieli do czynienia z roszczeniem - ustawodawca nie posługuje się takim terminem ani terminem podobnym, nie sprecyzowano też treści czynności dzierżawcy tak, aby można było uznać, że jest cywilnoprawnym oświadczeniem woli wywołującym skutek w postaci powstania obowiązku zawarcia umowy sprzedaży. Oświadczenie dzierżawcy dotyczące zamiaru nabycia nieruchomości jest także - co podkreśla SN - składane w zwykłej formie pisemnej a nie w formie aktu notarialnego i nie określa przedmiotowo istotnych elementów umowy sprzedaży, w tym ceny nieruchomości.

Wyjaśniając zaś, na czym polega swoistość regulacji art. 4 ust. 7 ustawy zmieniającej, Sąd Najwyższy wskazał, że ustawodawca wprowadził ,szerszy zakres uprawnień, swoiste przywileje tej grupy dzierżawców”, co przejawia się w „,wyprzedzeniu przez nich, w wypadku gdyby ANR (KOWR) zbywała nieruchomość, innych osób korzystających dotąd z pierwszeństwa przewidzianego w art. 29 u.g.n.r. (reguła kolizyjna)", pozbawieniu tego przywileju dzierżawców, którzy nie wyrazili zgody na wyłączenie 30\% użytków rolnych z umowy dzierżawy, uniezależnieniu pierwszeństwa od czasu trwania umowy dzierżawy, wprowadzeniu możliwości nabycia również części nieruchomości przez jej dzierżawcę, możliwości przedłużenia dzierżawy bez zastosowania procedury przetargu.

Jeśli chodzi o samą tezę uchwały SN, to ocenić ją należy jako trafną. Jednocześnie trzeba jednak zaznaczyć, że abstrahując od oceny słuszności poglądu Sądu Najwyższego na charakter sytuacji prawnej dzierżawcy, na tle art. 4 ust. 7 ustawy zmieniającej, nie sposób przeoczyć, iż sposób uargumentowania tezy uchwały nie jest zadowalający ${ }^{8}$.

Dla interpretacji art. 4 ust. 7 ustawy zmieniającej istotne jest określenie, co oznacza, że uprawnienie do nabycia nieruchomości ma nastąpić z zastosowaniem prawa pierwszeństwa, o którym mowa w art. 29 ust. 1 u.g.n.r.

W literaturze przedmiotu temat ten jest traktowany dość zdawkowo. Otóż M. Lemkowski w pierwszej kolejności stwierdza, że powyższy zwrot oznacza jedynie, iż odesłanie w art. 4 ust. 7 do zasad określonych w u.g.n.r. jest konieczne do określenia trybu sprzedaży, w tym zasad wyceny, natomiast stwierdzenie, że ma się to dokonać z zastosowaniem prawa pierwszeństwa, oznacza, iż uprawnienie do zakupu nie uchybiało pierwszeństwu przewidzianemu przez u.g.n.r., w szczególności cza, który formułuje i uzasadnia pogląd, zgodnie z którym dzierżawcy przysługuje roszczenie o zawarcie umowy; tenże, Glosa..., passim. 
roszczeniom ${ }^{9}$ byłych właścicieli nieruchomości ${ }^{10}$. Należy chyba rozumieć tę wypowiedź $\mathrm{w}$ ten sposób, że skorzystanie z uprawnienia przez dzierżawcę nie wyłącza obowiązków KOWR (ANR) dotyczących umożliwienia skorzystania z pierwszeństwa nabycia nieruchomości byłym właścicielom nieruchomości lub ich spadkobiercom.

Jeśli więc uznać, że zwrot ten oznacza, iż uprawnienie do zakupu nie uchybia pierwszeństwu innych podmiotów, to pojawia się podstawowy dylemat - jak miałoby się pierwszeństwo byłego właściciela, mające umocowanie w art. 29 ust. 1 pkt 1 u.k.u.r. do roszczenia przysługującego dzierżawcy z art. 4 ust. 7. Rozważyć trzeba, czy pierwszeństwo byłego właściciela jest ,pierwsze w kolejce” przed uprawnieniem dzierżawcy i jakie byłyby konsekwencje normatywne takiego postawienia sprawy.

Zgodnie z art. 29 ust. 3f u.g.n.r. w razie kolizji między pierwszeństwem osób wymienionych w ust. 1, przysługuje ono tym podmiotom w kolejności wskazanej w tym przepisie, co oznacza, że dzierżawca mógł skorzystać z pierwszeństwa dopiero gdy nie chciał skorzystać z niego były właściciel bądź jego spadkobierca. Przepis art. 29 ust. If u.g.n.r. dotyczy jednak kolizji między osobami, którym przysługuje pierwszeństwo, a nie dotyczy sytuacji, w której dzierżawcy przysługiwać miałoby roszczenie o zawarcie umowy, a byłemu właścicielowi albo jego spadkobiercom pierwszeństwo w nabyciu nieruchomości, a więc gdy pozycja prawna potencjalnego nabywcy (dzierżawcy i osoby, której przysługuje pierwszeństwo) różni się zasadniczo.

Art. 29 ust. 1f u.g.n.r. dotyczy wyłącznie kolizji między poszczególnymi kategoriami podmiotów uprzywilejowanych pierwszeństwem i nie sposób traktować go jako ustalający porządek preferencji między podmiotami, wśród których jest taki, który znajduje się w innej sytuacji prawnej niż przywilej pierwszeństwa. Art. 4 ust. 7 ustawy zmieniającej ani żaden inny przepis tego aktu prawnego nie zawiera

9 W tym kontekście nie da się jednak mówić o „roszczeniach byłych właścicieli”. Przysługiwało im pierwszeństwo, a to samo w sobie nie jest przecież równoznaczne $z$ jakimkolwiek roszczeniem.

10 M. Lemkowski, Uprawnienie dzierżawcy..., op. cit., s. 151. Autor w tym miejscu powołuje się na stanowisko A. Suchoń, która wskazuje, że stosując pierwszeństwo, w pierwszej kolejności nabyć grunty mogą byli właściciele bądź spadkobiercy tych osób (taż, Z prawnej problematyki..., op. cit., s. 75). Jak wiadomo, w związku z uchyleniem art. 29 ust. 1 pkt 1 u.g.n.r. obecnie pierwszeństwo nie przysługuje byłym właścicielom i ich spadkobiercom, jednak rozważenie kwestii poruszanych powyżej jest istotne ze względu na to, że prawodawca zakładając, iż dzierżawcy przysługiwać ma na gruncie ustawy zmieniającej w szczególny sposób uregulowane pierwszeństwo w nabyciu nieruchomości, to statuując regulację art. 4 ustawy zmieniającej musiał brać pod uwagę kwestię ewentualnej kolizji pierwszeństwa (czy też innej sytuacji prawnej) dzierżawców i innych podmiotów o wyższym niż dzierżawca pierwszeństwie, w tym przede wszystkim byłych właścicieli nieruchomości, o których mowa w uchylonym art. 29 ust. 1 pkt 1 u.g.n.r. Trzeba też zauważyć, że ANR, realizując obowiązki nałożone przez art. 4 ustawy zmieniającej w razie wyrażenia przez dzierżawcę zgody na wyłączenie części gruntów z umowy dzierżawy i zawarcia stosownego aneksu do umowy, w pierwszej kolejności umożliwiał nabycie nieruchomości w trybie pierwszeństwa byłym właścicielom nieruchomości i następnie umożliwiał nabycie dzierżawcy; zob. Zarządzenie nr 43/2011 Prezesa ANR z dnia 24 listopada 2011 r. w sprawie wyłączania z umów dzierżawy 30\% powierzchni użytków rolnych, http://www.kowr.gov.pl/o-kowr/zarzadzenia-prezesa-anr/zarzadzenie-nr-43-11-prezesa-anr-z-dnia-24-11-2011-r. 
Sytuacja prawna dzierżawcy w obrębie regulacji dotyczącej nabycia nieruchomości...

postanowień, które by ewentualnie mogły być interpretowane jako regulujące kolizję przysługujących różnym podmiotom: roszczenia o zawarcie umowy sprzedaży oraz pierwszeństwa w nabyciu nieruchomości.

Rozważyć należy następujące warianty rozwikłania tego problemu. Można rozważyć tezę, że pierwszeństwo byłego właściciela (jego spadkobiercy) wyprzedza roszczenie dzierżawcy. Oznaczałoby to, że dzierżawca, któremu przysługuje roszczenie o zawarcie umowy sprzedaży, mógłby je realizować przymusowo dopiero wówczas, gdyby były właściciel (jego spadkobierca) nie chciał realizować przysługującego mu pierwszeństwa. Stąd jeśli przed przeniesieniem własności na dzierżawcę zawarta zostałaby umowa sprzedaży w ramach realizacji pierwszeństwa nabycia z osobą uprzywilejowaną pierwszeństwem o wyższym priorytecie, roszczenie dzierżawcy wygasłoby (nie uległo aktualizacji).

Trudno byłoby określić w rozsądny sposób, jak kształtuje się sytuacja dzierżawcy, który oczekiwałby w kolejności za byłym właścicielem albo jego spadkobiercą na możliwość nabycia nieruchomości. Uprzywilejowany pierwszeństwem na gruncie postanowień art. 29 u.g.n.r. nie może (zgodnie z dominującym poglądem co do charakteru pierwszeństwa) w żaden sposób wymusić na KOWR (ANR) uruchomienia procedury realizacji pierwszeństwa przez KOWR (ANR) ani zawarcia umowy, nawet gdyby zaakceptował warunki zbycia nieruchomości przedstawione w zawiadomieniu o możliwości skorzystania z pierwszeństwa. Nie ma możliwości wymuszenia przez uprzywilejowanego zawarcia z nim przez KOWR (ANR) umowy sprzedaży. Skoro tak, to pojawia się problem, jak kształtuje się sytuacja dzierżawcy (który złożył oświadczenie o chęci zakupu nieruchomości i nastapiło wyłączenie części nieruchomości z dzierżawy) w razie braku woli zawarcia umowy ze strony KOWR względem uprzywilejowanego pierwszeństwem byłego właściciela (jego spadkobiercy) - czy taki stan tamowałby powstanie (czy też - aktualizację) roszczenia o zawarcie umowy przez dzierżawcę?

Abstrahując od braku przesłanek mających bezpośrednie oparcie w brzmieniu przepisów prawa, a przemawiających za słusznością zaproponowanego rozwiązania, nie ma też innych względów, które by uzasadniały takie stanowisko. Względy nazwać by je można konstrukcyjnymi - przemawiają raczej za prymatem roszczenia (jako postaci prawa podmiotowego) nad pierwszeństwem nabycia nieruchomości, które wszak zgodnie z dominującym poglądem jest słabszym przywilejem, pozbawionym kwalifikacji prawa podmiotowego. Trudno wskazać na racje funkcjonalne wskazujące na to, że pierwszeństwo osób o wyższym pierwszeństwie niż dzierżawca miałoby mieć również priorytet przed roszczeniem (istniejącym) dzierżawcy.

Interpretacja taka nie ma, jak wspomniano, wystarczającego zakotwiczenia w brzmieniu stosownych regulacji ustawy zmieniającej. Powstanie możliwości nabycia nieruchomości przez dzierżawcę, zgodnie z jej postanowieniami, jest uza- 
leżnione jedynie od zaakceptowania wyłączenia 30\% powierzchni z umowy dzierżawy, złożenia oświadczenia o skorzystaniu z prawa do zakupu i zmiany umowy dzierżawy. Innych przesłanek powstania „uprawnienia” $\mathrm{z}$ art. 4 ust. 7 przepisy ustawy zmieniającej wprost nie formułują.

Jeśli by więc odrzucić pogląd o możliwej kolizji pierwszeństwa byłego właściciela oraz roszczenia o zawarcie umowy przysługującego dzierżawcy i jednocześnie stać na stanowisku, że obie części art. 4 ust. 7 ustawy zmieniającej (pierwsza stanowiąca o uprawnieniu dzierżawcy oraz druga o zastosowaniu prawa pierwszeństwa) stanowią o różnych sytuacjach prawnych i mają przynajmniej w pewnym stopniu samodzielne znaczenie normatywne, to wartym rozważenia sposobem interpretacji tego przepisu byłoby przyjęcie, że część mówiąca o prawie pierwszeństwa odnosi się do technicznego sposobu realizacji roszczenia dzierżawcy z zastosowaniem odpowiednich regulacji u.g.n.r. dotyczących realizacji pierwszeństwa w nabyciu nieruchomości.

Analiza tego zagadnienia skłania jednak do uznania, że nie można zwrotu w art. 4 ust. 7 ustawy zmieniającej o zastosowaniu ,prawa pierwszeństwa” traktować jedynie jako odesłania do uregulowania u.g.n.r., ewentualnie też przepisów wykonawczych do u.g.n.r. tylko w zakresie czysto proceduralnym, czyli wskazującego, iż przysługujące dzierżawcy roszczenie realizowane jest w takim toku czynności jak określony dla realizacji pierwszeństwa (zawiadomienie przez KOWR [ANR] o możliwości sprzedaży z oznaczeniem ceny, oczekiwanie na odpowiedź, wskazanie terminu zawarcia umowy w razie pozytywnej reakcji dzierżawcy ${ }^{11}$ ).

Pomijając niedoskonałości omawianej regulacji w warstwie językowej, to jednak dość jasno postanowiono w treści art. 4 ust. 7, że stosuje się unormowanie dotyczące prawa pierwszeństwa, a nie wyłącznie sposobu (procedury) jego wykonania. Uregulowanie dotyczące sposobu realizacji pierwszeństwa - gdyby odnosić je do realizacji roszczenia o zawarcie umowy - nie byłoby adekwatne, z uwagi na inny charakter pierwszeństwa niż roszczenia. Tryb realizacji pierwszeństwa w u.g.n.r. jest dostosowany do cech tego instrumentu prawnego, z których na czoło wysuwa się (w każdym razie na etapie zawiadomienia uprzywilejowanego o przysługującym mu pierwszeństwie) brak roszczenia o zawarcie umowy, oraz to, że konkretyzacja ceny (jej wysokości) następuje w drodze decyzji sprzedającego ${ }^{12}$. Innymi słowy -

11 Zob. art. 29 ust. 1c-1f u.g.n.r., jak i § 5 rozporządzenia Ministra Rolnictwa i Rozwoju Wsi z dnia 30 kwietnia 2012 r. w sprawie szczegółowego trybu sprzedaży nieruchomości Zasobu Własności Rolnej Skarbu Państwa i ich części składowych, warunków obniżenia ceny sprzedaży nieruchomości wpisanej do rejestru zabytków oraz stawek szacunkowych gruntów (Dz.U. poz. 540).

12 KOWR (ANR) zgodnie ze swoją wolą określa cenę, nie będąc związany ściśle określonym przez ustawę górnym pułapem, na poziomie którego może ją określić. Jej dolną granicą jest zasadniczo, zgodnie z art. 30 u.g.n.r., cena rynkowa nieruchomości (cena ma być nie niższa niż wartość rynkowa nieruchomości). Wprawdzie górny pułap ceny nie został ustawowo określony, to należy uznać (posiłkując się orzecznictwem SN na tle pierwszeństwa w ustawie o gospodarce nieruchomościami), że cena nie może być ustalona na pułapie znacząco przewyższającym wartość rynkową nieruchomości; zob. wyrok SN z dnia 15 stycznia 2003 r.,sygn. akt IV CKN 1637/00; 
Sytuacja prawna dzierżawcy w obrębie regulacji dotyczącej nabycia nieruchomości...

uregulowanie procedury realizacji pierwszeństwa jest pochodną jego charakteru prawnego. Przepis art. 4 ust. 7 nie wskazuje nawet, aby uregulowania u.g.n.r. dotyczące pierwszeństwa miały być stosowane odpowiednio.

Trzeba też mieć na względzie, że - abstrahując od dalekiej od jednoznaczności treści art. 4 ust. 7 - samo użycie w nim słowa ,uprawnienie” nie musi wcale oznaczać, iż dzierżawcy przysługuje - zgodnie z wolą prawodawcy - roszczenie o zawarcie umowy sprzedaży. W orzecznictwie Sądu Najwyższego - co charakterystyczne - na tle regulacji pierwszeństwa w art. 29 u.g.n.r. nie przydaje się szczególnej wagi i nie wyciąga żadnych wniosków odnośnie charakteru pierwszeństwa w nabyciu nieruchomości w nawiązaniu i z odwołaniem do terminologii tej ustawy zawierającej - w obrębie regulacji pierwszeństwa w nabyciu nieruchomości również termin „uprawnienie” (vide art. 29 ust.1f u.g.n.r., zgodnie z którym w razie zbiegu uprawnień do pierwszeństwa w nabyciu nieruchomości stosuje się kolejność wymienioną w ust. 1 tego artykułu). W uchwale z dnia 7 października 2008 r. $^{13}$ Sąd Najwyższy, przychylając się do poglądu, zgodnie z którym pierwszeństwo nie jest prawem podmiotowym, w uzasadnieniu zaznaczył, że niektóre uregulowania u.g.n.r. skłaniają do konstatacji o przysługiwaniu prawa podmiotowego osobie, której przyznane zostało pierwszeństwo nabycia. Wskazuje, że w art. 29 ust. 1f u.g.n.r. ustawodawca posługuje się wprost określeniem „uprawnienie” w kontekście sytuacji podmiotów uprzywilejowanych pierwszeństwem. Zaraz jednak Sąd Najwyższy dodaje, że nie należy ze sformułowania zawartego we wskazanym przepisie wyciągać zbyt daleko idących wniosków, mając na względzie, iż specyfika obrotu nieruchomościami wymaga ostrożności przy wykładni pojęcia ,pierwszeństwo". W istocie więc posłużenie się przez prawodawcę terminem ,uprawnienie” w perspektywie regulacji pierwszeństwa zostało ocenione jako pozbawione jakiegokolwiek znaczenia normatywnego. W art. 4 ustawy zmieniającej mamy do czynienia z problematyką ściśle powiązaną z postanowieniami u.g.n.r., w tym regulacją pierwszeństwa; wniosek o potrzebie traktowania z rezerwą terminologii nawiązującej do „uprawnienia” w kontekście pierwszeństwa również na tle regulacji art. 4 ustawy zmieniającej wydaje się więc zasadny.

Ponadto - pozostając wciąż na gruncie kwestii terminologicznych i spójności działań prawodawcy w tym aspekcie - trzeba zwrócić uwagę, że w treści art. 4 ust. 7 ustawy zmieniającej mówi się o uprawnieniu do nabycia nieruchomości z zastosowaniem - verba legis - prawa pierwszeństwa. Ograniczając się do czysto literalnej wykładni (gdyby serio i konsekwentnie traktować terminologię ustawową jako efekt celowego działania prawodawcy liczącego się z utrwalonym znaczeniem poszczególnych terminów), należałoby skonstatować, że pierwszeństwo jest prawem

R. Michałowski, Charakter prawny oraz konsekwencje naruszenia pierwszeństwa w nabyciu nieruchomości Zasobu Własności Rolnej Skarbu Państwa, „Studia luridica Agraria” 2009, t. VII, s. 272.

13 Sygn. akt III CZP 95/08, „Orzecznictwo Sądu Najwyższego Izba Cywilna” 2009, nr 9, poz. 121. 
podmiotowym. Jak wspomniano wcześniej, w orzecznictwie Sądu Najwyższego dotyczącym pierwszeństwa na gruncie art. 29 u.g.n.r. neguje się jednak ujmowanie pierwszeństwa w kategorii prawa podmiotowego ${ }^{14}$, a używa - celem określenia sytuacji osoby, której pierwszeństwo przysługuje - terminu ,przywilej”. Stanowisko to nie budzi zasadniczo kontrowersji w doktrynie. Co zresztą nieco konfudujące, Sąd Najwyższy w uchwale z dnia 19 października 2017 r. pierwszeństwo dzierżawcy z art. 4 ustawy zmieniającej określa jako „bardzo słabe prawo podmiotowe" - a więc kwalifikuje je w sposób, którego przykładowo w ważnych dla analizowanej problematyki przywołanych już orzeczeniach z dnia 13 grudnia $2006 \mathrm{r}^{15}$ oraz uchwale z dnia 7 października 2008 r. wyraźnie unikał. Zapewne jest to spowodowane tym, że w art. 4 ust. 7 ustawy zmieniającej jest mowa wprost o ,prawie pierwszeństwa, o którym mowa w art. 29 ustawy", jakkolwiek nie jest to dostateczne uzasadnienie. Rzec by można nawet, że gdyby był to rzeczywisty powód zawarcia takiego sformułowania w uzasadnieniu uchwały, świadczyłoby to o niekonsekwencji w argumentacji Sądu Najwyższego. Reasumując - sposób użycia owej terminologii w treści art. 4 ust. 7, z nawiązaniem do pojęć „uprawnienia” i ,prawa pierwszeństwa", nie może być traktowany sam w sobie jako rozstrzygający dla rozwikłania zagadnienia charakteru sytuacji prawnej dzierżawcy w związku z wyłączeniem 30\% użytków rolnych z umowy dzierżawy.

Słusznie zwraca się uwagę w doktrynie i orzecznictwie, że regulacja art. 4 może być odczytywana jako dająca podstawę do przyjęcia, że dzierżawcy służy „,coś” więcej niż tylko pierwszeństwo według reguł ściśle ustanowionych w u.g.n.r. Nie oznacza to jednak moim zdaniem, że sytuacja prawna dzierżawcy nie może być po prostu pewną modyfikacją pierwszeństwa z zachowaniem jego cech konstytutywnych.

Obowiązek „uruchomienia procedury pierwszeństwa” w celu zawarcia umowy sprzedaży, w terminach wynikających z art. 4 ust. 8, w związku z wyłączeniem części użytków rolnych z umowy dzierżawy nie jest skorelowany z możliwością żądania przez jakąkolwiek osobę, przede wszystkim dzierżawcę, podjęcia tych czynności przez ANR (KOWR), któremu przysługuje pierwszeństwo konstrukcyjnie nieróżniące się od uregulowania zawartego w u.g.n.r., z zastrzeżeniem swoistości wskazanych przez Sąd Najwyższy w uchwale z dnia 19 października 2017 r. i o których mowa poniżej ${ }^{16}$.

14 Zob. jednak M. Lemkowski, który stwierdza, że pierwszeństwo jest „bardzo słabym prawem podmiotowym”; tenże, Uprawnienie dzierżawcy..., op. cit., s. 151. W wyroku Sądu Najwyższego z dnia 13 grudnia 2006 r., II CSK 302/06 (OSNC 2007 nr 11, poz. 170) mówi się o przywileju pierwszeństwa. O „prawie pierwszeństwa” mowa jest w przepisach ustawy o zasadach zbywania mieszkań będących własnością przedsiębiorstw państwowych, niektórych spółek handlowych z udziałem Skarbu Państwa, państwowych osób prawnych oraz niektórych mieszkań będących własnością Skarbu Państwa (Dz.U. z 2016 r., poz. 52).

15 Sąd Najwyższy w uzasadnieniu wymienionej uchwały wskazuje, że instytucja pierwszeństwa jest niekiedy określana jako „prawo pierwszeństwa” - ujmując to wyrażenie w tym kontekście w cudzysłów. Sąd Najwyższy konsekwentnie określa tam natomiast pierwszeństwo jako przywilej. 16 Jak też wymienionych w początkowej części niniejszego artykułu, a wskazanych w uchwale Sądu Najwyższego
z dnia 19 października 2017 r. 
Sytuacja prawna dzierżawcy w obrębie regulacji dotyczącej nabycia nieruchomości...

Konsekwencje naruszenia tego obowiązku przez KOWR (ANR) można rozpatrywać - mając na względzie treść art. 4 ust. 7 ustawy zmieniającej - w perspektywie ciążącej na KOWR (ANR) powinności naprawienia szkody, którą poniósł dzierżawca przez to, że nie zawarto z nim umowy sprzedaży. Konsekwencje odszkodowawcze przyjęte są w orzecznictwie sądowym i w przeważającej części literatury prawniczej jako skutek naruszenia „zwykłego” pierwszeństwa z art. 29 ust. 1 u.g.n.r. Jednak na gruncie tego „zwykłego” pierwszeństwa wynikającego z u.g.n.r., uprzywilejowany podmiot nie może wymusić zawarcia z nim umowy sprzedaży wykonanie czynności służących realizacji pierwszeństwa i w następstwie zawarcie umowy jest pozostawione inicjatywie i woli KOWR (ANR). Jeśli KOWR (ANR) nie wyraża w ogóle woli zbycia nieruchomości i nie inicjuje procedury jej zbycia osobie uprzywilejowanej pierwszeństwem, to nie wiążą się z tym żadne konsekwencje, w tym odszkodowawcze. Jeżeli zaś, przykładowo, na rzecz osoby trzeciej w drodze przetargu nastąi sprzedaż nieruchomości, względem której inny podmiot mógłby zrealizować przywilej pierwszeństwa (ale KOWR nie wykonał powinności związanych z zawiadomieniem uprzywilejowanego o pierwszeństwie, uniemożliwiając skorzystanie z niego), wówczas zgodnie z dominującym stanowiskiem w orzecznictwie sądów podmiot, którego przywilej został naruszony, w razie poniesienia szkody mógłby wystąić z roszczeniem odszkodowawczym względem KOWR (ANR).

Natomiast specyfika uregulowania zawartego $\mathrm{w}$ art. 4 ust. 7 polega na tym, że jeśli KOWR (ANR) nie stworzyłby możliwości skorzystania z pierwszeństwa dzierżawcy, o którym mowa w art. 4 ust. 7 ustawy zmieniającej (KOWR nie wykazywatby jakiejkolwiek aktywności w związku z czynnościami pozwalającymi na realizację jego pierwszeństwa) w terminie, w którym powinna nastąpić zgodnie z art. 4 ust. 8 ustawy zmieniającej, możemy mieć do czynienia z aktualizacją sankcji odszkodowawczej - w tym zakresie mamy do czynienia z cechą decydującą o swoistości regulacji art. 4 ust. 7 ustawy zmieniającej ${ }^{17}$. Trzeba przyznać, że sankcja odszkodowawcza może być traktowana nieraz jako iluzoryczna - jest to jednak pochodna generalnych ułomności instytucji pierwszeństwa w ogólności a nie ułomności wyłącznie regulacji art. 4 ustawy zmieniającej.

W podsumowaniu stwierdzić należy, że z art. 4 ust. 7 ustawy zmieniającej wynika pierwszeństwo w nabyciu nieruchomości przysługujące dzierżawcy $\mathrm{w}$ razie wyłączenia 30\% użytków rolnych z umowy dzierżawy, zmodyfikowane w stosun$\mathrm{ku}$ do zasadniczego uregulowania z art. 29 u.g.n.r. Cechy swoiste sytuacji prawnej dzierżawcy na tle uregulowania u.g.n.r. zostały wskazane w uchwale Sądu Najwyższego z dnia 19 października 2017 r. Ponadto trzeba wskazać na odrębności w zakresie stosowania sankcji odszkodowawczej związanej z naruszeniem pierwszeń-

17 Można by więc stwierdzić, że mamy do czynienia ze swoistym, jakkolwiek nieegzekwowalnym „uprawnieniem” dzierżawcy, o którym mowa w części ust. 7 art. 4 ustawy zmieniającej strony dzierżawcy. 
stwa. W przypadku uregulowania zawartego w art. 4 ustawy zmieniającej sankcja ta może znaleźć zastosowanie w razie naruszenia obowiązku umożliwienia skorzystania z pierwszeństwa i zawarcia umowy sprzedaży w terminie określonym zgodnie $\mathrm{z}$ ust. 8 art. 4. 
Sytuacja prawna dzierżawcy w obrębie regulacji dotyczącej nabycia nieruchomości...

LEGAL STAND OF THE LESSEE WITHIN THE MEANING OF THE REGULATION FOR THE ACQUISITION OF REAL ESTATE FROM THE AGRICULTURAL PROPERTY STOCK OF THE STATE TREASURY, IN THE EVENT OF EXCLUSION OF 30\% OF AGRICULTURAL LAND FROM THE LEASE CONTRACT

Keywords: lease, contact conclusion claim, priority in real estate acquisition

This article deals with the issue of legal position of lessees in a situation where part of agricultural (arable) land is excluded from the lease contract according to the provisions of the Act of 16 September 2011 amending the act on managing agricultural property of the State Treasury. This issue raises a number of interpretative doubts in connection with the extremely vague wording of the relevant provisions of the said act. In particular, controversy arises due to the parallel use, in the content of Article 4.7 of the Act, of the terms "authorisation" and "priority right". According to the position of the Supreme Court, in such a situation, the lessee is entitled only in terms of the acquisition of real estate. In literature and in a number of judgments of common courts, there is also a position according to which the lessee has a claim to conclude a sales contract. The analysis presented in the article leads us to a conclusion that under the regulation of Article 4.7 of the Act of 16 September 2011, the position according to which the lessee shall have priority in the purchase of real estate, is correct.

\section{Bibliografia:}

Lemkowski M., Uprawnienie dzierżawcy do zakupu nieruchomości rolnej w następstwie częściowego rozwiązania umowy dzierżawy, „Przegląd Prawa Rolnego” 2016, nr 1.

Michałowski R., Charakter prawny oraz konsekwencje naruszenia pierwszeństwa w nabyciu nieruchomości Zasobu Własności Rolnej Skarbu Państwa, „Studia Iuridica Agraria” 2009, t. VII.

Suchoń A., Z prawnej problematyki gospodarowania na dzierżawionych gruntach rolnych, „Studia Iuridica Agraria" 2011, t. IX.

Truszkiewicz Z., Glosa do uchwały Sądu Najwyższego z dnia 15 października 2017 r., III CZP 45/17, „Krakowski Przegląd Notarialny” 2018, nr 3. 